\title{
Educational Malpractice: The Impact of Including Creationism in High School Biology Courses
}

\author{
Randy Moore • Sehoya Cotner
}

Published online: 25 October 2008

(C) Springer Science + Business Media, LLC 2008

\begin{abstract}
College students whose recollections of their high school biology courses included creationism were significantly more likely to invoke creationism-based answers on questions derived from the Material Acceptance of the Theory of Evolution (MATE) instrument than were students whose recollections of their high school biology courses included evolution but not creationism. On average, students who were taught neither evolution nor creationism in their high school biology courses exhibited intermediary responses on the MATE instrument. These results suggest that (1) high school teachers' treatments of evolution and creationism have a lasting impact and (2) the inclusion of creationism in high school biology courses increases the probability that students accept creationism and reject evolution when they arrive at college. These results are discussed relative to the impact of high school biology courses on students' subsequent acceptance of evolution and creationism.
\end{abstract}

Keywords Evolution · Creationism · biology teachers . High school students · Material Acceptance of the Theory of Evolution (MATE)

Throughout the United States, high school biology teachers in public schools are under increasing pressure to include creationism and downplay or omit evolution in their biology courses (Eglin 1983; Ellis 1983; Goldsmith 2000; Kibbler 2001; Martin-Hansen 2008; Moore and Kraemer 2005; NSTA 2005; Randak 2001; Verango and Toppo

R. Moore $(\bowtie) \cdot$ S. Cotner

Biology Program, University of Minnesota,

MCB 3-104, 420 Washington Ave. SE,

Minneapolis, MN 55455, USA

e-mail: RMoore@umn.edu
2005; Zimmerman 1987). Some of these teachers - many of whom believe their undergraduate training did not prepare them to teach evolution effectively (Moore and Kraemer 2005) - succumb to these pressures. Indeed, numerous studies have documented that $20-40 \%$ of US biology teachers either include creationism in, or omit evolution from, their courses (Aguillard 1999; Bergman 1999; Bandoli 2008; Bowman 2008; Buckner 1983; Ellis 1983; Weld and McNew 1999; Osif 1977; Eglin 1983; Troost 1979; Matthews, 1996; Muller 1959; Nickels and Drummond 1988; Overman and Deckard 1977; Randak 2001; Riddle 1941; Shankar 1989; Tatina 1989; Zimmerman 1987). These teachers include creationism in their biology courses despite the facts that doing so is unconstitutional, contradicts the recommendations of numerous scientific professional societies, and often violates state educational standards (see discussions in Moore 2002a, 2002b, 2004a). Most of these teachers include only the Christian story of creation, which is usually presented as a scientific alternative to evolution (Moore 2008a). As Don Aguillard has noted, "Creationism is alive and well among biology teachers" (Moore 1999).

Although the studies cited above have documented the extent of creationism in high school biology classrooms, none of these studies have addressed the subsequent impact of including creationism in high school biology courses. For example, how does a student's exposure to creationism and/or evolution (or neither) in their high school biology course relate to students' subsequent acceptance of evolution and/or creationism? Are students who were taught evolution in high school more likely to accept evolution at college than are students who were taught neither evolution nor creationism? Are students who were taught creationism in their high school biology course more likely to subsequently accept creationism when they arrive at college? What are the consequences of exposure to neither 
evolution nor creationism in high school biology? Stated another way, does high school instruction in evolution and/or creationism really matter?

In this study we tried to determine the impact of students' evolution-related and creationism-related instruction in high school on students' subsequent attitudes about evolution and creationism in college. Specifically, we tried to answer the following questions:

- Are students who enter college believing in creationism more likely than nonbelievers to have had a high school biology course that included creationism?

- Are students who enter college accepting evolution more likely than nonacceptors to have had a high school biology course that included evolution?

- Are students whose high school biology course included neither evolution nor creationism more likely to accept evolution or creationism?

- Does an introductory biology course at college that emphasizes evolution change students' views of evolution?

\section{Methods}

During Fall 2007 and Spring 2008, we surveyed 728 undergraduate students in introductory nonmajors biology courses offered at the Twin Cities campus of the University of Minnesota. We used institutional data to determine that these students had an average high school graduation percentile of $83 \%$ and an average ACT composite score of 25. All of the students in this study had taken a biology course in high school.

Prior to the first week of classes we asked students, via an email solicitation on the part of their instructor, to tell us whether their high school biology course included evolution, creationism, both evolution and creationism, or neither evolution nor creationism. We also asked students to respond to eight statements from the Material Acceptance of the Theory of Evolution (MATE) instrument developed and validated by Rutledge and Sadler (2007). At the end of the semester, we repeated the survey with a voluntary subset of 69 students from our sample. A per-item comparison of means was conducted, using the Student's $t$-test for significant differences. Surveys had no impact on students' grades, students understood they were under no obligation to complete all survey items, and the authors obtained Institutional Review Board approval prior to starting the research. Surveys were completed online and tabulated electronically. Responses were analyzed categorically, using contingency-table analysis and Pearson's chi-square (JMP-IN 5.1.2, Cary, North Carolina). All differences reported are significant at $p<0.05$.

\section{Results}

Students' descriptions of their high school biology courses are shown in Table 1. Of the 728 responses, $64 \%$ of the students' high school biology courses included only evolution, $2 \%$ included only creationism, $21 \%$ included evolution and creationism, and $13 \%$ included neither evolution nor creationism.

Students' responses to the MATE questions are shown in Fig. 1. There was a consistent pattern in students' responses to statements concerning the theory of evolution, the age of the earth, and scientific consensus on evolutionary theory. Students whose high school biology course included evolution (but not creationism) were significantly more likely $(72 \%$ versus $58 \%)$ to accept the validity of evolutionary theory ("evolution is a scientifically valid theory"), science-based claims about the age of the earth, the mutability of species ( $75 \%$ versus $60 \%$ ), and humans being the product of evolution (71\% versus $55 \%)$. For example, in response to the statement "The age of the earth is at least four billion years," $64 \%$ of the evolution-only students selected "agree" or "agree strongly;" only $46 \%$ of the creationism-included respondents agreed; and $60 \%$ of the "neither" group agreed. However, students whose high school biology courses included creationism were significantly more likely to believe in a young earth and the immutability of species ( $28 \%$ versus $18 \%$ ), question the validity of evolutionary theory ( $18 \%$ versus $13 \%)$, and almost twice as likely ( $20 \%$ versus $12 \%$ ) to invoke a Biblical response to evolutionary theory ("the theory of evolution cannot be correct since it disagrees with the Biblical account of creation"). Regardless of their biology background, almost all (i.e., 88 and 91\%) students surveyed believed that scientists accept evolutionary theory.

A consistent pattern also emerged in the responses of those whose high school biology courses included neither evolution nor creationism. These students $(13.4 \%$ of the sample) represented a middle ground on the remaining seven MATE questions (i.e., all except the question about scientists' acceptance of evolutionary theory). For example, compared with students taught creationism in high school,

Table 1 Students' reports of their high school biology course

\begin{tabular}{llr}
\hline Response & Number & Percent \\
\hline My high school biology course included & & \\
Evolution only & 460 & 64.0 \\
Evolution and creationism & 147 & 20.5 \\
Creationism only & 15 & 2.1 \\
Neither evolution nor creationism & 96 & 13.4 \\
\hline
\end{tabular}

Students were all enrolled in introductory biology in Fall 2007 and Spring $2008(N=718$ respondents to this item, out of 728 surveys completed). Surveys were completed prior to the start of classes. 
Fig. 1 a Percentages of students who agreed with a creationistleaning statements, and $\mathbf{b}$ scientific statements regarding the origin and diversity of life on earth. Questions are from the Material Acceptance of the Theory of Evolution (MATE) instrument (Rutledge and Sadler 2007). Students are divided into categories depending on whether they report having evolution only $(N=460)$, creationism alone or with evolution $(N=162)$, or neither evolution nor creationism $(N=96)$ in high school biology. All differences statistically significant $(p<0.05)$ with contingency-table analysis, using Pearson's chi-square test. In addition, paired comparisons reveal statistically significant per-item differences in mean response between evolution and creationism (Student's $t$-test, $p<0.01$ for each item)
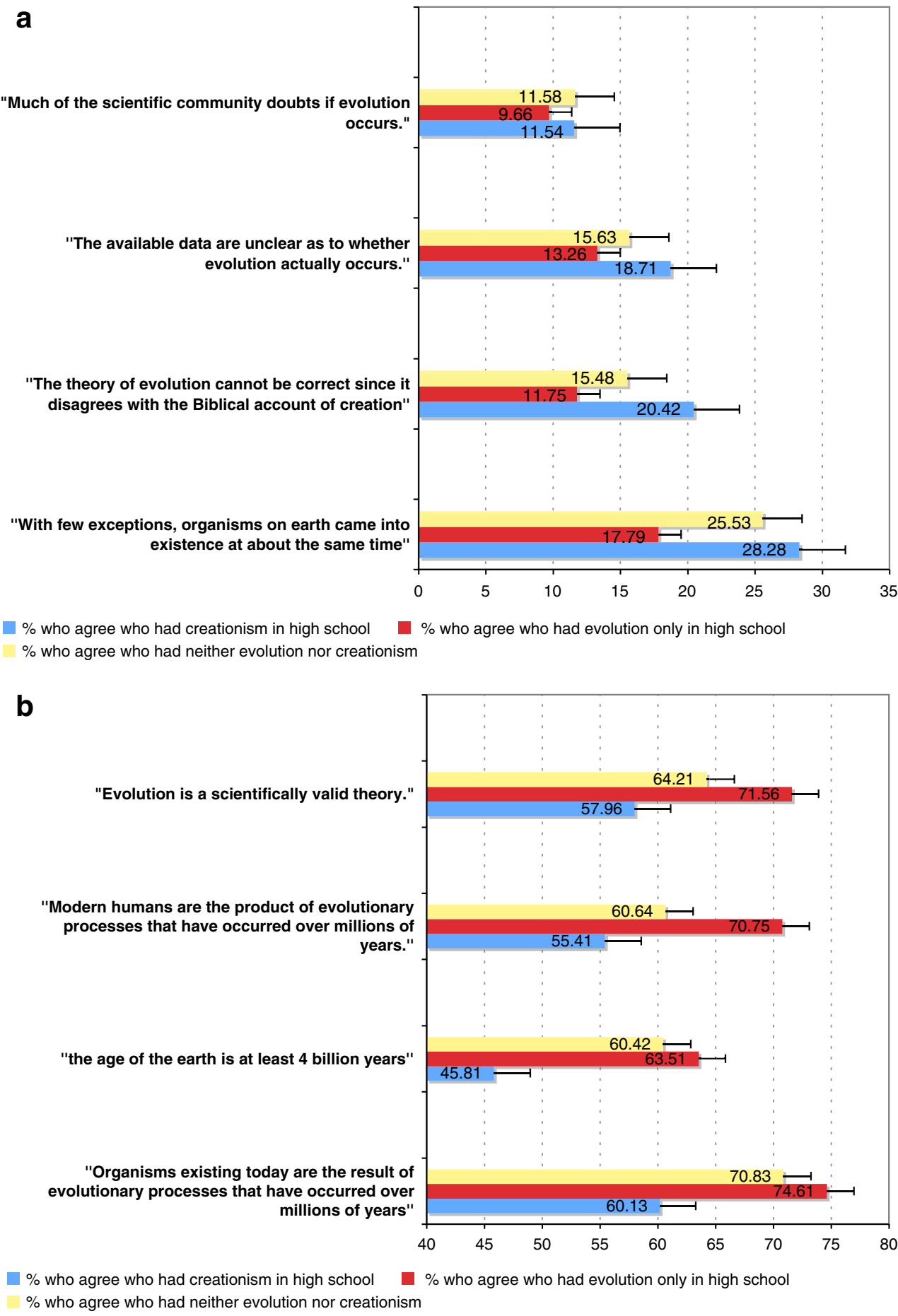

those exposed to neither evolution nor creationism were more likely to enter college biology accepting the scientific validity of evolution, the age of the earth, and the tempo of evolutionary change than were students whose high school biology classes included creationism (Fig. 1).

In the subsample of 69 students who were surveyed at the end of the semester, a matched-pairs analysis revealed no significant differences between pre-course and postcourse responses to the MATE questions.

\section{Discussion}

Limitations of the Study

Like all survey-based research, this study had several possible limitations. Although we gathered data from a large group of students over two semesters, all of the students in this study attended the same university and therefore are probably not a truly random sampling of all 
high school graduates. Similarly, students' recollections of their high school biology courses may not have been perfect; for example, some of the students may have discussed creationism in comparative religion and/or philosophy courses, and not in their biology course. It is also possible that a student's prior convictions might have shaped his or her recollections of high school biology with respect to the treatment of evolution or creationism. In addition, not all introductory biology students are first-year students and may have encountered discussions of evolution in other aspects of their college curriculum. Therefore, we do not assign a completely causative link to high school biology and acceptance of evolutionary theory.

Despite these possible limitations, much evidence suggests that the data reported here are reliable and representative. For example, our sample was large, and the results were similar each semester. Moreover, students' reports about the inclusion of evolution and creationism (or neither) in their high school biology courses are consistent with those reported by biology teachers in Minnesota (Kraemer 1995; Moore 2008b; Moore and Kraemer 2005) and other studies elsewhere (Aguillard 1999; Bandoli 2008; Randak 2001; Rutledge and Mitchell 2002; Tatina 1989; Trani 2004; Weld and McNew 1999; and references therein). As is true in many other states, the state science education standards of Minnesota (i.e., where most of the students in this study attended high school) mandate the teaching of evolution, and Minnesota's professional organizations of science teachers (e.g., Minnesota Science Teachers Association) endorse the teaching of evolution and reject the teaching of creationism (Moore 2004b). Nevertheless, creationism continues to be included in almost one-fourth of high school biology classes in virtually all states that have been studied (see references above).

\section{Creationism and Evolution Education in High Schools}

Most (i.e., 63\%) high school biology teachers teach evolution and not creationism (Table 1). That is, these teachers comply with the state educational guidelines and recommendations from professional organizations of science teachers (e.g., "only evolution should be taught in science classes because it is the only scientific explanation for why the universe is the way it is today;" National Academy of Sciences 1998, 1999). Relatively few of these teachers are pressured to teach evolution (Moore and Kraemer 2005). Our finding that approximately $90 \%$ of students believe that scientists accept evolution is consistent with the report that similar percentages of high school biology teachers acknowledge that scientists accept evolutionary theory (Moore and Kraemer 2005).

Although only $2 \%$ of biology teachers at public schools teach creationism and not evolution, more than $20 \%$ of biology teachers at public schools teach both evolution and creationism. Similar percentages have been reported in other studies in other states (Bandoli 2008; Moore and Kraemer 2005 and references therein), and the amount of class time devoted to creationism in public schools is increasing (Moore and Kraemer 2005). Likewise, students' claims that approximately $25 \%$ of biology courses include creationism are consistent with the fact that almost onefourth of Minnesota's biology teachers believe that creationism has a valid scientific foundation (Moore and Kraemer 2005 and references therein).

Teachers who best understand evolution and the nature of science allocate more time to evolution and do a better job of teaching it (Rutledge and Mitchell 2002). Thus, the inclusion of creationism in some biology teachers' courses may be partly due to the teachers' poor understanding of the nature of science. Indeed, the nature of science is seldom emphasized in most science classrooms (Dodick and Orion 2003), and more than one-third of biology teachers were not biology majors (National Center for Education Statistics 2003). Not surprisingly, then, many biology teachers question evolution (Bandoli 2008 and references therein) and claim that they are not prepared to teach evolution (Kraemer 1995; Moore and Kraemer 2005; Tatina 1989; Zimmerman 1987). This may be due to the fact that many future biology teachers do not take courses that adequately or effectively emphasize evolution or the nature of science (Rutledge and Mitchell 2002; Rutledge and Warden 2000). For example, more than $40 \%$ of high school biology teachers in Indiana and Ohio only mentioned evolution or did not discuss it at all in thier classes (Bandoli 2008; Rutledge and Mitchell 2002), and many biology teachers in Louisiana do not recall hearing the word evolution in their college biology courses, presumably because many college biology professors do not teach evolution (Moore 1999, 2002a). The situation may worsen, for less than half of pre-service elementary teachers accept Darwin's theory of evolution, and almost $90 \%$ of students preparing to teach science in elementary school (and 63\% of students preparing to teach secondary science) want other views, including "the divine origin of life through special creation," to be taught with evolution (Kibbler 2001; also see Troost 1979). This inclination, combined with biology teachers' confusion about, or ignorance of, several major evolution-related court decisions (e.g., Edwards v. Aguillard 1987; McLean v. Arkansas Board of Education 1982; see discussion in Moore 2004a), is likely to perpetuate the inclusion of nonscientific creation myths in biology classrooms.

Another reason for the inclusion of creationism in high school biology classrooms may be teachers' religious beliefs (Trani 2004 and references therein). Teachers' personal views of a subject influence their teaching of the subject (Carlesen 1991; Grossman 1989), and individuals having the strongest religious beliefs are most likely to reject 
evolution (Lawson and Worsnap 1992). Since relatively large percentages of high school biology teachers are creationists (many of whom reject evolution while claiming that creationism is scientifically valid; see Kraemer 1995; Moore and Kraemer 2005), it is not surprising that many biology teachers who include creationism in their courses do so because of their religious beliefs (Trani 2004).

\section{Does it Matter if Teachers Teach Creationism?}

Our results indicate that the inclusion of creationism in high school biology classes significantly increases the probability that students accept creationism and reject evolution when they arrive at college. We do not mean to imply that a student's experience with evolution and/or creationism in high school is the sole determinant of their subsequent views of these subjects in college. Yet our data suggest that high school teachers' inclusion of creationism in their biology courses may have a strong and lasting impact and that students are significantly affected by their high school biology teachers' treatments of evolution and creationism (also see Bandoli 2008). Although exposure to creationism in high school is not strongly correlated with a particular type of creationism in college (e.g., intelligent design, dayage, progressive creationism, etc.; see Moore 2008a), students' misconceptions often remain "well ingrained even after a thorough coverage of the evidences supporting evolution" in college (see discussion in Johnson and Peeples 1987). In fact, our data suggest that the omission of evolution from high school biology courses may be preferable to a mixed approach that validates nonscientific explanations of diversity (Fig. 1).

We were disappointed to see that the introductory biology course did not significantly affect students' response to the MATE questions. Similar responses have been reported by others (e.g., Martin-Hansen 2008; Robbins and Roy 2007). This shortcoming may have resulted from our instruction, students' poor understanding of the nature of what science is and how it is done (college students' acceptance of evolution is influenced by their understanding of the nature of science; see Johnson and Peeples 1987), or to the students having worldviews that conflict with science (Coburn 1991). Regardless, these results suggest that students' high school experiences in biology have a greater impact on students' acceptance of evolutionary theory than does a single college-level introductory biology course.

In 1991, Eve and Harrold (1991) concluded that "over a quarter - and perhaps as many as half - of the nation's high school students get educations shaped by creationist influence - in spite of the overwhelming opposition of the nation's scientific, educational, and media establishments" (p. 166). Data presented here and elsewhere indicate that little has changed; surprisingly high percentages of high school biology teachers in the United States continue to teach creationism, and the products of this teaching are students primed to discount a fundamental tenet of modern biology. This educational malpractice denies students an appreciation of the nature of science, contributes to the ongoing popularity of creationism with the public, and cheats students out of an understanding of one of the greatest ideas in history.

\section{References}

Aguillard D. Evolution education in Louisiana public schools: A decade following Edwards v. Aguillard. Am Biol Teach 1999;61:182-8.

Bandoli JH. Do state science standards matter? Comparing student perceptions of the coverage of evolution in Indiana and Ohio public high schools. Am Biol Teach. 2008;70:212-6. doi:10.1662/0002-7685(2008)70[212:DSSSM]2.0.CO;2.

Bergman J. The attitude of various populations toward creation and evolution in public schools. Creation Ex Nihilo Tech J. 1999;13 (2):118-23.

Bowman KL. The evolution battles in high school science classes: Who is teaching what? Retrieved March 19, 2008, from http:// www.frontiersinecology.org.

Buckner E. Professional and political socialization: High school science teacher attitudes on curriculum decisions, in the context of the "scientific" creationism campaign. Unpublished doctoral dissertation, Georgia State University, Atlanta, GA; 1983.

Carlesen S. Effects of new biology teachers' subject-matter knowledge on curricular planning. Sci Educ. 1991;757:631-47.

Coburn W. Worldview theory and science education research. NARS Monograph No. 3. Manhattan, KS: National Association for Research in Science Teaching; 1991.

Dodick J, Orion N. Geology as an historical science: Its perception within science and the education system. Sci Educ. 2003;12:197211. doi:10.1023/A:1023096001250.

Edwards v. Aguillard, 482 U.S. 578. 1987.

Eglin P. Creationism versus evolution. A study of the opinions of Georgia science teachers. Unpublished doctoral dissertation, Georgia State University, Atlanta, GA; 1983.

Ellis W. Creationism in Kentucky: The response of high school biology teachers. Science and creationism New York: Macmillan; 1983. p. 72-91.

Eve R, Harrold F. The creationist movement in modern America. Boston: Twayne; 1991.

Goldsmith T. The evolution wars. Sci Teach. 2000;67:8.

Grossman PL. Learning to teach without teacher education. Teachers College Record. 1989;91:191-208.

Johnson RL, Peeples EE. The role of scientific understanding in college student acceptance of evolution. Am Biol Teach. 1987;49:93-8.

Kibbler A. Teaching critical thinking: Evolution in the classroom. Retrieved January 29, 2004 from www.indiana.edu/ alumni/ magtalk/jan-feb01/evolution.html

Kraemer KA. A comparative study of Minnesota teachers' attitudes toward the teaching of evolution and creationism. Unpublished Master's thesis, Bemidji State University, Bemidji, MN; 1995.

Lawson A, Worsnop W. Learning about evolution and rejecting a belief in special creation: Effects of reflective reasoning skill, prior knowledge, prior belief and religious commitment. J Res Sci Teach. 1992;29:143-66. doi:10.1002/tea.3660290205. 
Martin-Hansen LM. First-year college students' conflict with religion and science. Sci Educ. 2008;17:317-57. doi:10.1007/s11191006-9039-5.

Matthews CE. Fossil finds. Sci Scope. 1996;19(7):13-6.

McLean v. Arkansas Board of Education, 529 F. Supp. 1255, (E.D. Ark. 1982)

Moore R. The courage and convictions of Don Aguillard. Am Biol Teach. 1999;61:166-74.

Moore R. Evolution in the courtroom: A reference guide. Santa Barbara, CA: ABC-CLIO; 2002a.

Moore R. Teaching evolution: Do state standards matter? Bioscience. 2002b;52(4):378-81. doi:10.1641/0006-3568(2002)052[0378: TEDSSM $] 2.0 . \mathrm{CO} ; 2$.

Moore R. How well do biology teachers understand the legal issues associated with the teaching of evolution? Bioscience. 2004a;54 (9):2-7.

Moore R. State standards and evolution: Are standards relevant to the teaching of evolution in public school biology classrooms. Sci Teach. 2004b;71(6):41-4.

Moore R. The evolution-creationism continuum in college biology classrooms. College Board AP Central. Retrieved March 12, 2008, from http://apcentral.collegeboard.com/apc/members/ courses/teachers corner/185212.html; 2008a.

Moore R. Creationism in the biology classroom: What do teachers teach and how do they teach it. Am Biol Teach. 2008b;70(2):79 84. doi:10.1662/0002-7685(2008)70[79:CITBCW]2.0.CO;2.

Moore R, Kraemer K. The teaching of evolution and creationism in Minnesota. Am Biol Teach. 2005;67:457-66. doi:10.1662/00027685(2005)067[0457:TTOECI]2.0.CO;2.

Muller HJ. One hundred years without Darwinism are enough. Humanist. 1959;19:139.

National Academy of Sciences. Teaching about evolution and the nature of science. Washington, DC: National Academy Press; 1998.

National Academy of Sciences. Science and creationism. 2nd ed. Washington, DC: National Academy Press; 1999.

National Center for Education Statistics. The condition of education. Washington, DC: U.S. Government Printing Office; 2003.

National Science Teachers Association. Survey indicates science teachers feel pressure to teach nonscientific alternatives to evolution. Retrieved February 16, 2008, from http://www.nsta. org/publications/surveys/survey20050324.aspx; 2005.

Nickels MK, Drummond BA. Creation/evolution: Results of a survey conducted at the 1983 ISTA convention. Creation/Evolution Newsletter. 1988;5(6):2-15.
Osif BA. Evolution and religious beliefs: A survey of Pennsylvania high school teachers. Am Biol Teach. 1977;59:552-6.

Overman R, Deckard S. Origins beliefs among American science teachers. Retrieved January 24, 2004 from http://www.icr.org/ pubs/imp/imp-292.htm; 1977.

Randak S. The children's crusade for creationism. Am Biol Teach 2001;63:226, 228, 230. doi:10.1662/0002-7685(2001)063[0226: TCSCFC $] 2.0 . \mathrm{CO} ; 2$.

Riddle O. Preliminary impressions and facts from a questionnaire on secondary school biology. Am Biol Teach. 1941;3:151-9.

Robbins JR, Roy P. The natural selection: Identifying and correcting nonscientific student preconceptions through an inquiry-based, critical approach to evolution. Am Biol Teach. 2007;69(8):460 6. doi:10.1662/0002-7685(2007)69[460:TNSICN]2.0.CO;2.

Rutledge ML, Mitchell MA. High school biology teachers' knowledge structure, acceptance, and teaching of evolution. Am Biol Teach. 2002;64:21-8. doi:10.1662/0002-7685(2002)064[0021: HSBTKS]2.0.CO;2.

Rutledge ML, Warden WA. Evolutionary theory, the nature of science and high school biology teachers: Critical relationships. Am Biol Teach. 2000;62:23-31. doi:10.1662/0002-7685(2000)062[0023: ETTNOS]2.0.CO;2.

Rutledge ML, Sadler KC. Reliability of the Measure of Acceptance of the Theory of Evolution (MATE) instrument with university students. Am Biol Teach. 2007;69(6):332-5. doi:10.1662/00027685(2007)69[332:ROTMOA]2.0.CO;2.

Shankar G. Analysis of factors influencing the teaching of evolution and creationism in Texas public high school biology classes. Unpublished doctoral dissertation, Texas Tech University, Lubbock, TX; 1989.

Tatina R. South Dakota high school biology teachers and the teaching of evolution. Am Biol Teach. 1989;51:275-80.

Trani R. I won't teach evolution, it's against my religion; And now for the rest of the story. Am Biol Teach. 2004;66:419-27. doi:10.1662/0002-7685(2004)066[0419:IWTIAM]2.0.CO;2.

Troost JC. An analysis of factors influencing the teaching of evolution in the secondary schools of Indiana. Unpublished doctoral dissertation, Indiana State University, Bloomington, IN; 1979.

Verango D, Toppo G. (March 24). "Call to arms" on evolution. USA Today, p. B5; 2005.

Weld J, McNew JC. Attitudes toward evolution. Sci Teach. 1999; $66: 27-31$.

Zimmerman M. The evolution-creation controversy: Opinions of Ohio high school biology teachers. Ohio J Sci. 1987;87:115-25. 